Висновки. Запропонована структура інтелектуально-творчого потенціалу вчителя технологій розкриває складність цього особистісного утворення i наявність великої кількості інтегрованих компонентів (спадкових і набутих), за допомогою яких досягаються творчі результати.

Психолого-педагогічний аспект проблеми ІТП пов'язаний з виявленням, діагностуванням та розвитком його компонентів. Перспективи подальших розвідок у даному напрямку передбачають розроблення й застосування психологопедагогічних умов організації інтелектуально-творчої діяльності задля формування названого особистісного утворення в майбутніх учителів технологій.

Завдання викладачів - сформувати інтелектуально-творчий потенціал у майбутніх учителів технологій, завдання майбутнього фахівця - ефективно його використати і реалізувати в майбутній професійній діяльності.

\title{
Література
}

1. Айзенк Г. Ю. Интеллект: новый взгляд / Г. Ю. Айзенк ; [пер. с англ. А. В. Александровой] // Вопросы психологии. - 1995. - № 1. - С. 111-131.

2. Ильин Е. П. Психология творчества, креативности, одаренности / Евгений Павлович Ильин. - СПб. : Питер, 2009. - 434c. - (Серия «Мастера психологии»)

3. Лук А. Н. Мышление и творчество / Александр Наумович Лук. - М. : Политиздат, 1970. - 144 с. - (Философ. б-чка для юношества).

4. Мішіна Л. М. Інтелектуальний потенціал творчої особистості / Л. М. Мішіна // Рідна школа. - 2009. - № 10. - С. 15-18.

5. Панкратова А. А. Практический, социальный и эмоциональный виды интеллекта: сравнительный анализ / А. А. Панкратова // Вопросы психологии. - 2010. № 2. - С. 111-119.

6. Психологічне дослідження творчого потенціалу особистості : [монографія] / авт. кол., наук. керівник В. О. Моляко. - К. : Педагогічна думка, 2008. - 208 с.

7. Холодная М. А. Психология интеллекта: парадоксы исследования : [моногафия] / Марина Александровна Холодная. - [2-е изд., перераб. и доп.]. - СПб. : Питер, 2002. - 272 с.

Стаття надійшла до редакції 16.05.2012 p.

УДК 371.15

Н. Кипиченко, викладач, Київський університет імені Бориса Грінченка

\section{КОМУНІКАТИВНА КОМПЕТЕНТНІСТЬ МАЙБУТНЬОГО ВЧИТЕЛЯ ПОЧАТКОВОЇ ШКОЛИ ЯК ПСИХОЛОГО-ПЕДАГОГІЧНА ПРОБЛЕМА}

Кипиченко Н. Комунікативна компетентність майбутнього вчителя початкової школи як психолого-педагогічна проблема.

У статті розглянуто основні підходи вітчизняних $і$ зарубіжних науковиів до визначення сутності та структури комунікативної компетентності; уточнено сутність та зміст поняття «комунікативна компетентність учителя початкової школи», визначено структурні компоненти комунікативної компетентності майбутнього вчителя початкової школи.

Ключові слова: компетентність, компетенція, комунікативна компетентність майбутнього вчителя початкової школи, мовна компетенція, мовленнєва компетенція, сочіолінгвістична компетенція. 
Кипиченко Н. Коммуникативная компетентность будущого учителя начальной школь как психолого-педагогическая проблема.

В статье рассмотрены основные подходы отечественных и зарубежных ученых $\kappa$ определению сущности и структуры коммуникативной компетентности; уточнены сущность и содержание понятия «коммуникативная компетентность будущего учителя начальной школь», определены структурные компоненты коммуникативной компетентности будущего учителя начальной школьь.

Ключевые слова: компетентность, компетенция, коммуникативная компетентность будущего учителя начальной школь, языковая компетенщия, речевая компетенция, соииолингвистическая компетениия.

Kipichenko N. Communicative competence of future teachers of elementary school as a psychological and pedagogical problem.

The article reviews the main approaches of domestic and foreign scientists to determine the nature and structure of communicative competence, the essence and meaning of "communicative competence of primary school teachers» defined structural components of communicative competence of primary school teacher.

Key words: competence, communicative competence of primary school teachers, language competence, sociolinguistic competence.

Постановка й обгрунтування актуальності проблеми. Реформування системи вищої професійної освіти вимагає вдосконалення фахової підготовки педагогічних кадрів, яка $є$ підгрунтям педагогічної майстерності вчителів, обов'язковою умовою їх професійної компетентності. Аналізуючи сучасну теорію та практику, можна стверджувати, що недостатньо вивчено і розроблено теоретичні засади формування у майбутніх учителів початкової школи комунікативної компетентності. Отже, існує нагальна потреба опрацювання $\mathrm{i}$ поширення результатів наукових розвідок науковців у цьому напрямку.

Аналіз наукових досліджень. Аналіз широкого кола наукових джерел засвідчив, що в педагогічній науці приділяється значна увага проблемі комунікативної підготовки педагогів. Теоретичні й методичні засади формування комунікативної компетентності майбутніх учителів досліджували О. Аршавська, О. Бєляєв, М. Васильєва, М. Вашуленко, Л. Виготський, Н. Волкова, М. Вятютнєв, Н. Гез, А. Годлевська, Є. Голобородько, М. Жинкін, Д. Ізаренков, І. Зимняя, В. Кан-Калик, А. Капська, Ю. Караулов, Р. Козьяков, М. Коць, Т. Ладиженська, Л. Мацько, Н. Пашківська, М. Пентилюк, В. Півторацька, В. Підгурська, С. Савіньон, Л. Савенкова, Г. Сагач, О. Скворцова, О. Яковліва та інші.

Водночас попри наявні теоретико-методичні розвідки, зауважимо, що виокремлені наукові дослідження стосуються лише деяких аспектів, порушуючи частину проблем безмежного загалу комунікативної підготовки майбутніх фахівців початкової освіти.

3 урахуванням зазначеного, мета статті - здійснити науковий аналіз проблеми сутності та структури комунікативної компетентності майбутніх учителів початкової школи у психолого-педагогічній літературі.

Виклад основного матеріалу. Грунтовне вивчення психолого-педагогічної літератури засвідчило, що в науці триває інтенсивна дискусія навколо визначення сутності дефініції «компетентність». Наявні різні тлумачення цієї категорії, які хоч принципово й не відрізняються, проте визначають i підкреслюють різні аспекти цього поняття. Ми підтримуємо думку академіка 
О. Савченко, яка розглядає компетентність як інтегровану здатність особистості, набуту у процесі навчання, що охоплює: знання, вміння, навички, досвід, цінності, які можуть цілісно реалізуватися на практиці [7, c. 416]. Поділяємо погляди С. Мартиненко, яка вважає, що «професійна компетентність полягає в умінні самостійно формулювати педагогічні задачі та знаходити їх оптимальне розв'язання» [5, с.79].

Нас цікавить комунікативна компетентність, яка є одним із складників професійної компетентності вчителя початкової школи, тому зупинимось детальніше на характеристиці їі структури.

Вивчення психолого-педагогічної літератури з досліджуваної проблеми засвідчило, що існують два основні підходи до визначення сутності та змісту комунікативної компетентності. Так, О. Аршавська, М. Вятютнєв, Д. Ізаренков, С. Савіньон, О. Скворцова та інші розглядають окреслену дефініцію через поняття «здатності», тобто як здатність використовувати мову в різних сферах спілкування $[1 ; 2 ; 8 ; 11]$. М. Вятютнєв виокремлює такі складники комунікативної компетентності: розумові здібності особистості та мовленнєву діяльність. Науковець розуміє під комунікативною компетентністю здатність використовувати мову творчо, цілеспрямовано, нормативно, у взаємодії зі співрозмовником [1, с. 34]. Д. Ізаренков визначає іiі як здатність людини до спілкування в одному, кількох або всіх видах мовленнєвої діяльності, що становить набуту в процесі природної комунікації або спеціально організованого навчання особливу властивість особистості [2, с. 54-60]. О. Скворцова також підкреслює, що у тлумаченні поняття «комунікативна компетентність» передбачається така ознака як наявність здібностей до педагогічної комунікації [7]. Отже, за цим підходом розвиток комунікативної компетентності вчителя початкової школи залежить від його здібностей.

За іншим підходом (Н. Гез, О. Казарцева, О. Краєвська, Г. Рурік, Ю. Федоренко, Д. Хаймс та інші) науковці трактують цей термін шляхом зіставлення його з поняттями «знання, уміння та навички». Так, Н. Гез висловлює думку, що комунікативна компетентність охоплює знання про мову, навички та вміння застосовувати їх у мові в різних ситуаціях спілкування [3; 5; 9; 10]. О. Казарцева та Ю. Федоренко виокремлюють знання, уміння та навички, необхідні для розуміння чужих та породження власних продуктів мовленнєвої діяльності, адекватних цілям, сферам i ситуаціям спілкування [3; 8]. Г. Рурік зазначає, що володіння певною системою вмінь і навичок міжособистісного спілкування, адекватних ситуації спілкування і достатніх для досягнення поставленої суб'єктом комунікативної мети є комунікативною компетентністю [6, с. 344-380]. Отже, науковці вважають, що комунікативна компетентність є явищем як лінгвістичним, так i педагогічним, оскільки вона співвідноситься із знаннями, вміннями та навичками, які найбільш точно віддзеркалюють багатогранність комунікативної компетентності, iї важливу роль у формуванні особистості. 
Узагальнюючи вище викладене, можемо стверджувати, що комунікативна компетентність майбутніх учителів початкової школи охоплює знання, вміння і навички, які формуються у процесі фахової підготовки.

Нами встановлено, що у психолого-педагогічній літературі наявні різні підходи до визначення структурних елементів комунікативної компетентності. 3 позиції практичного використання найбільший інтерес, на наше глибоке переконання, викликає комунікативна компетентність учителя початкової школи як основа ефективної організації навчально-виховного процесу, тому вважаємо за доцільне визначити та проаналізувати піi компонентний склад.

На думку М. Вятютнєва, вона складається із знань граматики, лексики, правил спілкування, етикетних формул, мовленнєвих засобів [1, с. 34]. Однак Н. Гез уважає, що важливим є також такий компонент, як уміння співвідносити мовні засоби із завданнями, умовами спілкування і розуміння стосунків між комунікантами. О. Аршавська вважає іiі основними структурними компонентами мовну і соціальну компетенції, які входять до структури будь-якої діяльності.

Дещо іншу структуру подає Ю. Федоренко, яка виокремлює такі компетенції, а саме: мовну (лексичні, граматичні, фонетичні й орфографічні знання), мовленнєву (охоплює вміння аудіювання, читання, письма та мовленнєві вміння), лексичну (знання лексики i мовленнєві лексичні навички), граматичну (знання граматики і мовленнєві граматичні навички), фонетичну (фонетичні знання, мовленнєво-слухо-вимовні навички), соціокультурну (стосується країнознавства та лінгвокраїнознавства) та компетенцію, що пов’язана з процесом говоріння [9, с. 63-65].

Згідно з поглядами С. Савіньон, структуру комунікативної компетентності утворюють такі компетенції, як: граматична (граматичний рівень речення), соціолінгвістична (розуміння соціального контексту, у якому використовується мова), дискурсивна (вміння продукувати текст) і стратегічна (компенсація часткових знань, умінь та навичок). Особливу увагу дослідниця акцентує на останній, що має компенсувати часткові знання мови у процесі професійної діяльності [11, с. 129-134].

Погляди зарубіжних дсолідників дещо відрізняються. Так, проаналізувавши наукові праці, ми встановили, що Б. Шпітсберг та У. Купа виокремили три компоненти комунікативної компетентності, а саме: мотивація, знання (процесуальні знання про те, яку стратегію поведінки обрати в конкретній ситуації), навички (використовувані типи поведінки), тобто це взаємозалежність когнітивного, поведінкового та афективного компонентів у певних мовленнєвих актах. Інші науковці вважають, що комунікативна компетентність охоплює знання, навички, чутливість (здатність виявляти увагу і повагу), зобов'язання (прагнення уникати помилок і знаходити ефективні шляхи взаємодії у процесі самоосвіти та самовдосконалення). Однак дослідники зосереджують увагу на тому, що рівень володіння комунікативною компетентністю залежить від контексту, у якому відбувається взаємодія [10]. 
Д. Ізаренков уважає, що більшість науковців описують компетенції як самодостатні явища, незважаючи на те, що мають виявити компоненти, базисні складові комунікативної компетентності. Науковець запропонував три компетенції, які складають іiі модель, а саме: мовну (вміння будувати граматично правильні й усвідомлені висловлювання), предметну (відповідає за зміст висловлювання і забезпечує одержання знань про той фрагмент світу, який $є$ предметом мовлення) і прагматичну (здатність використовувати висловлювання в певних мовленнєвих актах, співвідносячи їх із умовами спілкування) [2, с. 54-60].

Ми схиляємось до думки науковців, які вважають основними структурними компонентами комунікативної компетентності мовну, мовленнєву та соціолінгвістичну компетенції. Зупинимось детальніше на їх характеристиці.

Мовна компетенція визначається нами як певна система знань про українську мову як складне соціокультурне явище і сформовані на цій основі мовні вміння, а саме: фонетичні, орфоепічні, морфемні, лексичні, синтаксичні. До ii основних характеристик відносимо мовленнєві задатки, знання мови, реалізацію мови у мовленні. Загальновідомо, що передача будь-якої інформації можлива лише за допомогою знаків та знакових систем. Розрізняють вербальну і невербальну комунікації, що використовують різноманітні знакові системи. Відповідно до цього можна виокремити вербальний і невербальний рівні комунікативного складника компетентності в спілкуванні. Вербальна комунікація застосовує як знакову систему людську вимову, природну звукову мову, тобто систему фонетичних звуків, що охоплює два принципи: лексичний та синтаксичний.

Мовленнєва компетенція охоплює певні знання про точність, влучність, адекватність, правильність використання мовних засобів, знання про особливості використання мовних засобів залежно від типу, стилю мовлення, знання особливостей використання зображувально-виражальних засобів мови, про особливості усного й писемного мовлення, його діалогічну та монологічну форми та є одним із компонентів професійної готовності, реалізації професійного потенціалу майбутнього вчителя початкової школи. Розвинені мовленнєві вміння, за твердженням науковців, $є$ показником педагогічної культури і педагогічної майстерності вчителя. Звичайно, формування професійно значущих мовленнєвих умінь, комунікативної культури відбувається під впливом психофізіологічних, соціокультурних і педагогічних чинників, які сприяють засвоєнню студентами знань про мовленнєву культуру і можливості ії застосування відповідно до потреби, особливостей та мети організації педагогічного процесу.

Соціолінгвістична компетенція, на нашу думку, $є$ інтегративним утворенням, оскільки акумулює знання та вміння, необхідні для соціального аспекту використання мови (правил ввічливості, норм, що регулюють стосунки між поколіннями, статями, класами, соціальними групами) визначається динамікою соціальної стратифікації суспільства, культурною орієнтацією його громадян; позитивною соціальною мотивацією людини 
тощо. Усе це загалом характеризує відносну стабільність, традиційність і посилює збереження культурологічної лінії у процесі формування професійних мовленнєвих умінь.

Отже, на основі здійсненого аналізу можна зробити висновок, що комунікативна компетентність учителя початкової школи - це система внутрішніх ресурсів ефективного розв'язання фахових завдань, а саме: позицій спілкування, ролей, стереотипів, настанов, знань, умінь, навичок, яка певним чином пов'язана 3 цілісністю особистості. Визначені іiі компоненти не протиставляються один одному, оскільки відображають багатозначність та складність дефініції, що розглядається, а також допомагають більш повному його розумінню й тлумаченню. 3 огляду на це рівень компетентності педагога визначається нами як показник того, наскільки успішно він виконує ті чи ті види діяльності, як здатність досягати ефективних результатів у навчально-виховному процесі, самоосвіті, самовихованні, тому на сучасному етапі розвитку освіти важливим $\epsilon$ сформованість комунікативної компетентності майбутнього вчителя початкової школи як необхідної умови формування комунікативної компетентності учнів молодшого шкільного віку.

\section{Література}

1. Вятютнев М. Н. Традиции и новации в современной методике преподавания русского языка / М. Н. Вятютнев // Научные традиции и новые направления в преподавании русского языка и литературы. - М., 1986. - 34 с.

2. Изаренков Д. И. Базисные составляющие коммуникативной компетенции и их формирование на продвинутом этапе обучения студентов нефилологов / Д.И. Изаренков // Русский язык за рубежом. - 1990. - №4. - С.54-60.

3. Казарцева О. М. Культура речевого общения: теория и практика обучения: [учеб. пособ.] / О. М. Казарцева. - [2-е изд.]. - М. : Флинт, Наука, 1999. - 499 с.

4. Коммуникативная компетентность. Стратегии, тактики, виды общения. [Электронный ресурс]. - Режим доступу: http://pro-psixology.ru/socialnopsixologicheskiefenomeny/133-kommunirativnaya-kompetentnost-strategii-taktiki.html

5. Мартиненко С. М. Діагностична діяльність майбутнього вчителя початкових класів: теорія і практика: [монографія] / С. М. Мартиненко. - К. : КМПУ імені Б. Д. Грінченка, 2008. - 434 с.

6. Рурік Г. Л. Комунікативна компетентність як складова професійної майстерності вчителя та засіб побудови гуманних взаємин між учасниками навчально-виховного процесу / Г. Л. Рурік // Формування професійної компетентності майбутнього вчителя в умовах вищого навчального закладу: [наук. пос.]. - К. : ВД «Слово», 2011. - С. 344-380.

7. Савченко О. Я. Дидактика початкової школи: [підруч. для студ. пед. ф-тів] / О. Я. Савченко. - К. : Абрис, 1997. - 416 с.

8. Скворцова А. И. Комунікативний компонент професійної компетентності вчителя математики [Електронний ресурс]. - Режим доступу: http: www.nbuv.gov.ua/portal/Soc_Gum/Npd/2010_2/Scvorcov.pdf

9. Федоренко Ю. С. Комунікативна компетенція як найважливіший елемент успішного спілкування / Ю. С. Федоренко // Рідна школа. - 2002. - № 1. - С. 63-65.

10. Communication competence defined! Dr Lane's Perspective [Електронний pecypc]. - Режим доступу: http: www.uky.edu/ drlane/captone/commcomp.htm

11. Savignon S. Evolution of Communicative Competence The ACTFL Provisional Proficiency Guidelines / S. Savignon //The Modern Language Journal. - 1995. - Vol. 95. - P. 129-134.

Стаття надійшла до редакції 23.05.2012 p. 